\title{
Influence of Duffy antigen receptor for chemokines on HIV infection
}

\author{
Robin Weiss \\ From Frontiers of Retrovirology: Complex retroviruses, retroelements and their hosts \\ Cambridge, UK. 16-18 September 2013
}

\section{Background}

Duffy antigen receptor for chemokines (DARC) binds inflammatory chemokines including several that also bind to CCR5. A recessive DARC allele which blocks expression on red cells affects $\sim 90 \%$ of sub-Saharan Africans but very few people of non-African origin. Approximately $50 \%$ of DARC null people show African benign neutropenia. We have investigated whether DARC acts as an HIV co-receptor and whether the null phenotype affects risk of HIV infection.

\section{Materials and methods}

DARC was expressed in CD4+ cells to test if it acts as an attachment or entry co-receptor for HIV-1 and HIV2. Genotyping of cohorts exposed to HIV-1 with respect to DARC FyA, FyB and Fy null alleles was conducted to assess its affect on neutropenia, CCL5 plasma levels and relative risk of HIV-1 infection.

\section{Results}

HIV-2 strains but not HIV-1 strains utilised DARC as an entry co-receptor. However, HIV-1 could bind to DARC on red cells and be delivered to activated CD4+ T-cells resulting in subsequent infection. GWAS analysis confirmed the link between DARC null genotype and African benign neutropenia. The DARC null phenotype with African benign neutropenia resulted in low CCL5 plasma levels and increased the relative risk of HIV-1 infection approximately 3 -fold.

\section{Conclusion}

The African-specific DARC null allele increases risk of HIV infection.

Published: 19 September 2013

Division of Infection \& immunity, University College London, London, UK
doi:10.1186/1742-4690-10-S1-031

Cite this article as: Weiss: Influence of Duffy antigen receptor for chemokines on HIV infection. Retrovirology 2013 10(Suppl 1):O31.
Submit your next manuscript to BioMed Central and take full advantage of:

- Convenient online submission

- Thorough peer review

- No space constraints or color figure charges

- Immediate publication on acceptance

- Inclusion in PubMed, CAS, Scopus and Google Scholar

- Research which is freely available for redistribution

Submit your manuscript at www.biomedcentral.com/submit

\section{() Biomed Central}

